J. AMER. SOC. HORT. SCI. 118(1):63-67. 1993.

\title{
Incidence and Severity of Crown and Root Rots on Four Apple Rootstocks Following Exposure to Phytophthora Species and Waterlogging
}

\author{
W.F. Wilcox \\ Department of Plant Pathology, Cornell University, New York State Agricultural Experiment Station, \\ Geneva, NY 14456 \\ Additional index words. collar rot, M.7, M.26, MM.111, 0.3, Malus ×domestica, Phytophthora cactorum, Phytophthora \\ cambivora, Phytophthora cryptogea, Phytophthora megasperma

\begin{abstract}
Plants of four apple (Malus ×domestica Borkh.) rootstock clones, M.7, M.26, MM.111, and Ottawa (O.) 3, were grown in unamended potting medium or in the same medium infested with Phytophthora cactorum (Leb. \& Cohn) Schroet., P. cambivora (Petri) Buisman, P. cryptogea Pethyb. \& Laff., or P. megasperma Drechsler, causal agents of crown and root rots. Plants were flooded for either $0,24,48$, or 72 h every 7 days for 4 months, then assessed for disease incidence and severity. Averaged across all pathogens and rootstocks, mean crown rot incidences were $2.5 \%, 6.3 \%, 19 \%$, and $50 \%$ following weekly flooding periods of $0,24,48$, and $72 \mathrm{~h}$, respectively; when averaged across all rootstocks and flooding treatments, mean incidences of crown rot caused by $P$. cryptogea, $P$. cactorum, $P$. cambivora, and $P$. megasperma were $36 \%$, $\mathbf{2 6 \%}, \mathbf{1 5 \%}$, and $\mathbf{8 . 8 \%}$, respectively; when averaged across all four pathogens, mean crown rot incidences after $72 \mathrm{~h}$ of flooding were $40 \%, 45 \%, 50 \%$, and $75 \%$ for M.26, 0.3, M.7, and MM.111, respectively. In contrast, 72-h flooding periods in the absence of a pathogen were least detrimental to growth of MM.111 clones and most detrimental to shoot growth of M-26. Exceptions to general trends were reflected by statistical interactions among pathogens, rootstocks, and flooding durations, e.g., after 72-h floodings, 0.3 was the rootstock with the greatest amount of root rot caused by $P$. cryptogea but the least amount caused by $P$. megasperma. Differential disease susceptibility among rootstocks appeared greatest with respect to $P$. cactorum and least with respect to $P$. cryptogea.
\end{abstract}

Crown, collar, and root rots caused by various Phytophthora spp. are debilitating and often fatal diseases of apple trees, occurring in most production regions of the world (Jeffers and Wilcox, 1990). Although various factors have contributed to a declining importance of scion infections (collar rot) over the last generation, the widespread adoption of clonal size-controlling rootstocks during this same period has been accompanied by increased outbreaks of crown and root rots on the clonal stocks themselves (Jeffers and Wilcox, 1990; McIntosh, 197.5).

Apple rootstocks vary widely in their susceptibility to Phytophthora crown and root rots, yet rankings of relative susceptibility to these diseases are usually subjective and often differ significantly among authorities. Whereas MM.104 and MM.106 are generally regarded as being among the most susceptible clones, some workers also have considered M.7, M.26, and/or MM.111 to be highly susceptible; others have considered one or more of this latter group to be only moderately susceptible, yet others have rated one or more as "never" encountering Phytophthora problems (Childers, 1983; McIntosh, 1975). Such inconsistency may result from unrecognized interactions among Phytophthora spp. and rootstock genotypes, from ratings derived primarily from empirical observations of disease frequencies in orchards associated with widely different horticultural practices, climates, and soil factors, and from the results of certain controlled tests that correlate poorly with rootstock performance under orchard conditions.

Root and crown rots caused by $P$. cactorum, $P$. cambivora, $P$. cryptogea, and $P$. megasperma are common on some clonal apple rootstocks in New York, particularly in soils that are chronically wet or subjected to periods of water logging (Jeffers and Aldwinckle,

Received for publication 25 Mar. 1992. Accepted for publication 15 Aug. 1992. The cost of publishing this paper was defrayed in part by the payment of page charges. Under postal regulations, this paper therefore must be hereby marked advertisement solely to indicate this fact.
1986; Merwin et al., 1992). This latter observation has led to some controversy concerning the relative importance of anoxia ("wet feet") vs. fungal parasitism on the decline and death of trees in such sites. The purpose of this experiment was to determine the main and interactive effects of various Phytophthora spp. and waterlogging regimes on the incidence and severity of crown and root rots on four apple rootstocks.

\section{Materials and Methods}

In a recent study (Jeffers and Aldwinckle, 1988), virtually all clonal rootstock samples obtained from 11 nurseries in North America and Europe were contaminated with $P$. cactorum or $P$. cambivora; therefore, the rootstock clones examined in the present experiment, M.7, M.26, MM.111, and Ottawa (O.) 3, were confined to those for which plants were obtainable from a source (AgriForest Technologies, Kelowna, B.C., Canada) employing micropropagation and subsequent plant production in a potting medium free ofpotentially contaminated field soil. After purchase, plants were grown in a greenhouse in individual pots containing $\approx 300 \mathrm{~cm}^{3}$ of potting mix ( 2 volumes fine vermiculite : 1 volume steam-pasteurized sandy loam) until their lower stems were welllignified and shoots were $\approx 10$ to $15 \mathrm{~cm}$ long. They then were transplanted into 1-liter plastic containers filled with the same potting mix that was either unamended or infested with inoculum of a single isolate of either $P$. cactorum (isolate no. NY 359), $P$. cambivora (NY 216), P. cryptogea (NY 353), or P. megasperma (NY 352) originally recovered from diseased apple trees in New York. Inoculum consisted of vermiculite that had been soaked with dilute vegetable juice broth and colonized by the test fungus, as described previously by Wilcox (1989), and was added at a rate of $30 \mathrm{~cm}^{3}$ per $1000 \mathrm{~cm}^{3}$ of potting medium.

Two weeks after transplanting, and at 7-day intervals thereafter, plants from each rootstock $\times$ Phytophthora $\mathrm{sp}$. combination were 
flooded for either 24,48 , or $72 \mathrm{~h}$ by plugging the drainage hole at the bottom of each container and adding water until 5 to $10 \mathrm{~mm}$ of free water collected on the soil surface; a fourth group of plants from each combination was left unflooded. Plants were otherwise watered daily with unimpeded drainage and fertilized biweekly with half-strength Hoagland's solution. The experiment was conducted for 4 months in a greenhouse maintained at 18 to $24 \mathrm{C}$ with a $15-\mathrm{h}$ photoperiod. The potting mix then was washed from each root system, crown rot incidence was determined, and disease severity was rated on the basis of the fresh weights of roots and shoots and a visual estimate of the percentage of the root system that was rotted. There were five replicate plants per treatment arranged in a completely randomized-block design.

To facilitate comparisons among rootstock clones of inherently different size and vigor, shoot and root fresh weights for individual plants in a rootstock $\mathrm{x}$ pathogen $\mathrm{x}$ flooding duration treatment were expressed and analyzed as a percentage of the mean weight of the five uninoculated control plants for the same rootstock $x$ flooding duration combination. Similarly, to compare effects of periodic waterlogging events in the absence of a Phytophthora sp., root and shoot weights of individual uninoculated plants in each flooding treatment were expressed as a percentage of the mean weight of the five unflooded control plants for the same rootstock. Analysis of variance (ANOVA) was performed on arcsin-transformed values of all root rot and fresh weight percentage data.

\section{Results}

Crown rot incidence was highly variable, depending on rootstock, pathogen, and flooding duration (Table 1). For instance, averaged across all pathogens and rootstocks, mean disease incidences were $2.5 \%, 6.3 \%, 19 \%$, and $50 \%$ following weekly flooding periods of $0,24,48$, and $72 \mathrm{~h}$, respectively. When averaged across all rootstocks and flooding treatments, mean incidences of crown rot caused by $P$. cryptogea, $P$. cactorum, $P$. cambivora, and $P$. megasperma were $36 \%, 26 \%, 15 \%$, and $8.8 \%$, respectively, and when averaged across all four pathogens, mean crown rot incidences in the most disease-conducive $(72 \mathrm{~h})$ flooding treatment were $40 \%, 45 \%, 50 \%$, and $75 \%$ for M.26, O.3, M.7, and MM.111, respectively. Apparent differences in susceptibility among rootstocks were greatest with respect to $P$. cactorum $(20 \%$ incidence for M.26 vs. $100 \%$ incidence for MM.111 with $72 \mathrm{~h}$ of flooding) and least with respect to P. cryptogea (80\% to $100 \%$ incidence for all rootstocks in the 72-h flooding treatment) (Table 1). No crown rot developed on plants grown in uninfested potting medium.

Table 1. Incidence of crown rot and severity of root rot caused by four Phythophthora spp. on four apple rootstocks subjected to various flooking treatments.

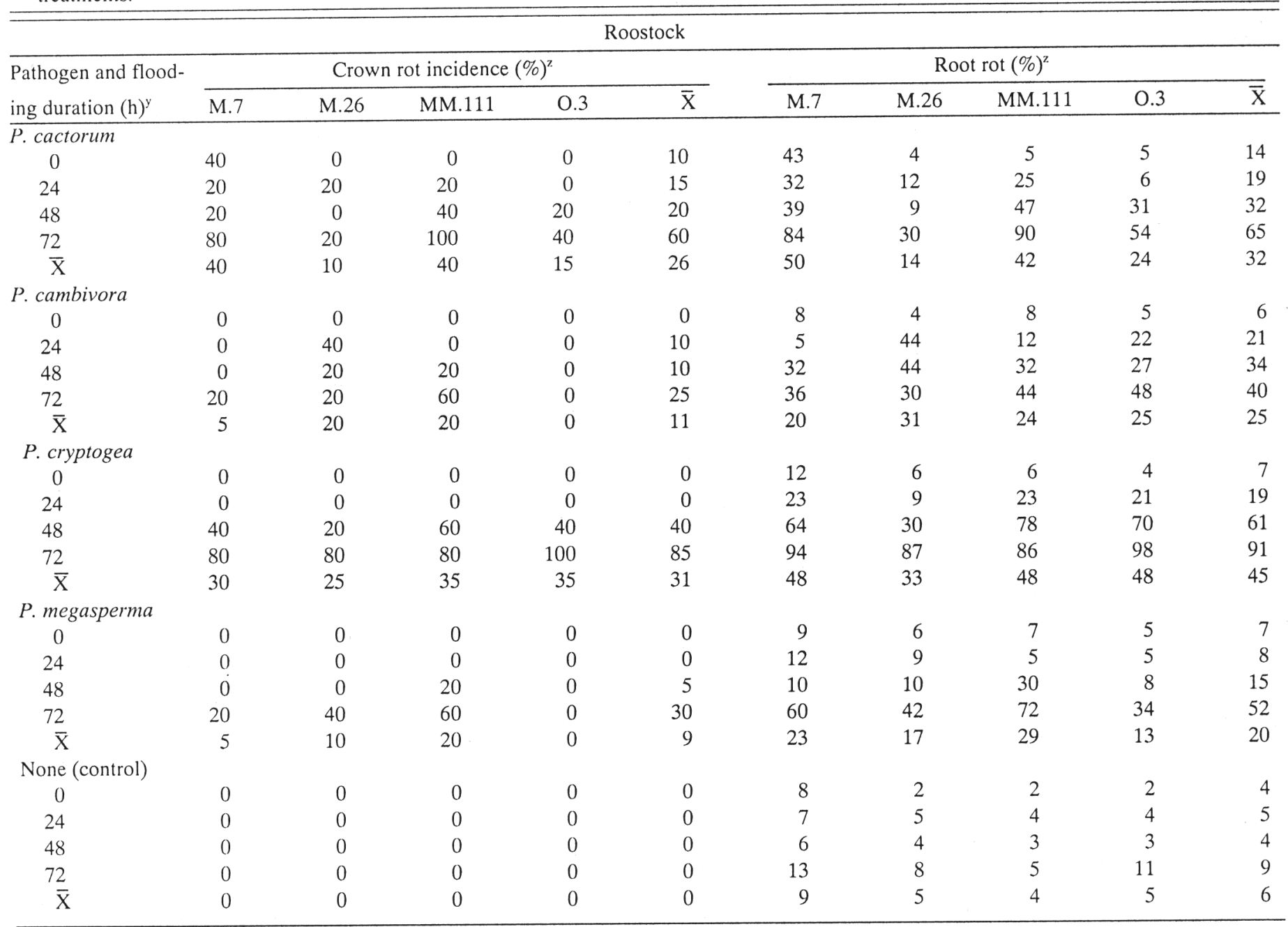

${ }^{2}$ Values represent the means from five replicate plants per treatment.

${ }^{y}$ Indicated flooding durations imposed every 7 days throughout the 4 -month duration of the experiment. 
Table 2. Relative shoot and root weights of four apple rootstock subjected to various flooding treatments in the presence or absence of four Phytophthora
species.

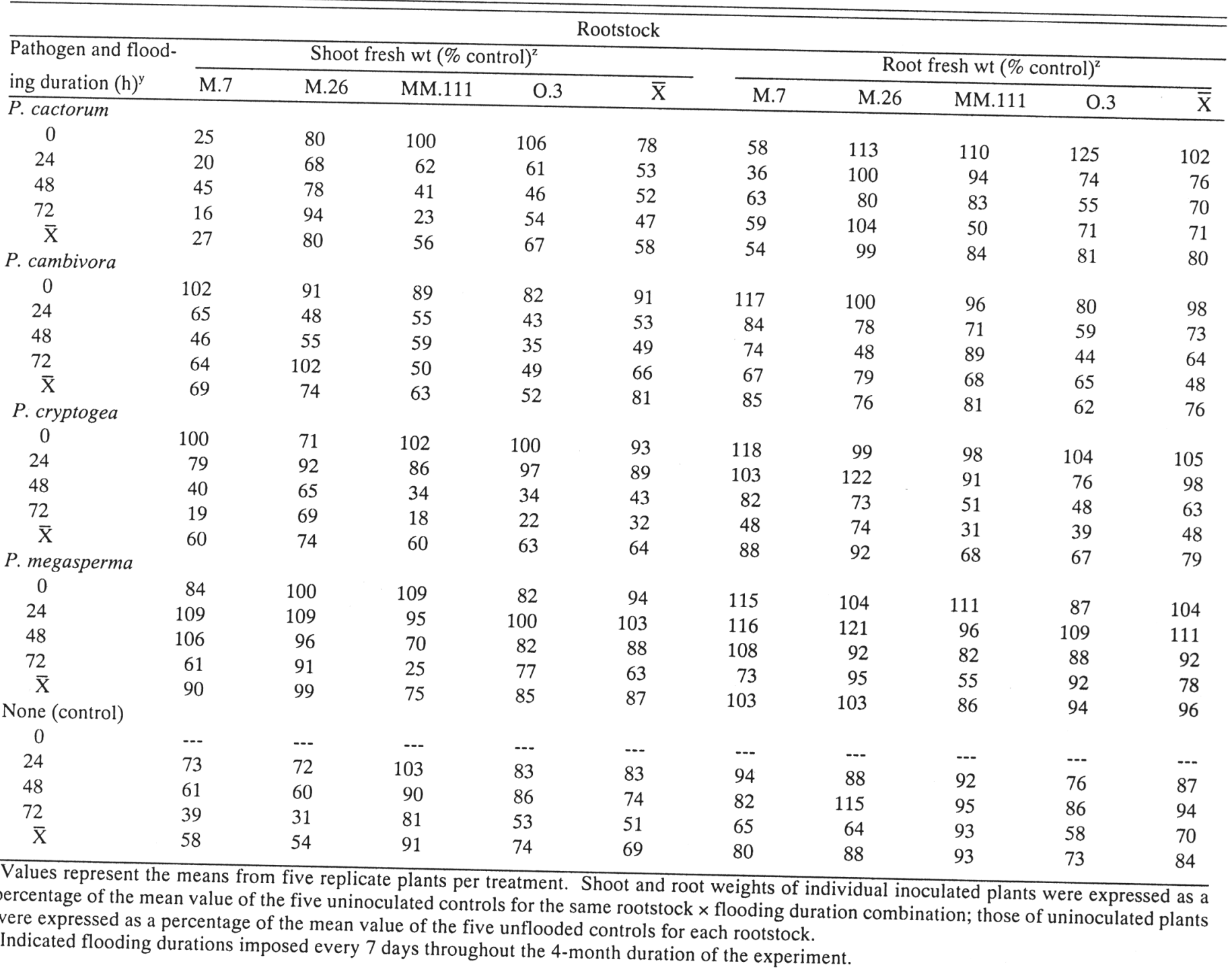

Estimated root rot percentages and the relative shoot and root weights for plants in individual treatments varied widely (Tables 1 and 2). ANOVA for all three measures of disease severity showed a highly significant $(P<0.001)$ contrast between infested and uninfested substrate (Table 3 ). The main effects of pathogen species, rootstock, and flooding duration were also highly significant (Table 3). The data in Tables 1 and 2 illustrate the highly significant linear component of the flooding duration effect and the significant to highly significant pathogen $\times$ flooding duration interactions revealed by the ANOVA for each measure of disease severity (Table 3). For instance, when averaged across all rootstocks P. cryptogea caused $7.0 \%, 19 \%, 60 \%$, and $91 \%$ root rot after 0,24 , 48 , and $72 \mathrm{~h}$ of flooding, respectively, whereas $P$. megasperma caused $6.8 \%, 7.8 \%, 14 \%$, and $52 \%$ root rot after the same respective flooding treatments. The highly significant pathogen $\mathrm{x}$ rootstock interaction for root rot percentages (Table 3) is also illustrated in Table 1, e.g., after repeated 72-h floodings, O.3 was the rootstock suffering the most root rot caused by $P$. cryptogea $(98 \%)$, whereas it was the rootstockleast affected by P. megasperma $(34 \%$ root rot). Root rot was only $2.0 \%$ to $13 \%$ among uninoculated controls, regardless of rootstock or flooding duration.
The depressions in shoot and root weights relative to control treatments generally were correlated with estimated root rot percentages for the infested but not for the uninfested treatments. Differences among treatments often were more pronounced for shoot than for root weights (Table 2), as indicated by the respectively lower F-statistic probability for some sources of variation (Table 3). Generally, the imposition of flooding treatments in the presence of a Phytophthora sp. was most deleterious to the final shoot weights of M.7 and MM.111 plants and least deleterious to those of M.26. In contrast, weekly 72-h flooding treatments in the absence of a pathogen reduced shoot weights of MM.111 plants by only $19 \%$ relative to unflooded controls, but reduced those of M.26 plants by $69 \%$ (Table 2 ). Such data are reflected by the highly significant infest $\times$ rootstock $\times$ flood time interaction (Table 3 ).

\section{Discussion}

Although the main effects of Phytophthora sp. (or absence thereof), rootstock clone, and flooding duration were highly pronounced, the interactions among these factors vividly illustrate the complications in rating rootstocks for general susceptibilities to 
Table 3. F-statistic probability from ANOVA for three measures of disease severity in an experiment examining the effect of four Phytophthora spp. (or lack thereof) and four weekly flooding treatments on four apple rootstock.

\begin{tabular}{|c|c|c|c|}
\hline \multirow[b]{2}{*}{$\begin{array}{l}\text { Source of } \\
\text { variation }^{2}\end{array}$} & \multicolumn{3}{|c|}{ Measure of disease severity } \\
\hline & $\begin{array}{c}\text { Root } \\
\operatorname{rot}(\%)^{y}\end{array}$ & $\begin{array}{c}\text { Shoot } \\
\text { wt }(\%)^{y x}\end{array}$ & $\begin{array}{c}\text { Root } \\
\text { wt }(\%)^{y x}\end{array}$ \\
\hline Infest & $<0.001$ & $<0.001$ & $<0.001$ \\
\hline Infest $\times$ pathogen & $<0.001$ & $<0.001$ & 0.002 \\
\hline Infest $\times$ rootstock & 0.003 & $<0.001$ & $<0.001$ \\
\hline Infest $\times$ flood time & $<0.001$ & $<0.001$ & $<0.001$ \\
\hline Linear & $<0.001$ & $<0.001$ & $<0.001$ \\
\hline Quadratic & 0.002 & 0.188 & 0.550 \\
\hline Deviations & 0.761 & 0.585 & 0.034 \\
\hline Infest $\times$ pathogen $\times$ rootstock & $<0.001$ & 0.092 & 0.021 \\
\hline Infest $\times$ pathogen $\times$ flood time & $<0.001$ & $<0.001$ & 0.030 \\
\hline Linear & $<0.001$ & 0.064 & 0.098 \\
\hline Quadratic & 0.008 & $<0.001$ & 0.016 \\
\hline Deviations & 0.211 & 0.049 & 0.581 \\
\hline Infest $\times$ rootstock $\times$ flood time & 0.468 & $<0.001$ & 0.202 \\
\hline Linear & 0.073 & $<0.001$ & 0.133 \\
\hline Quadratic & 0.852 & 0.874 & 0.160 \\
\hline Deviations & 0.736 & 0.805 & 0.712 \\
\hline
\end{tabular}

Infest $=$ the contrast between infested and nonifested treatments; infest $\times$ pathogen $=$ the variation between pathogens within the infested treatments; infest $\times$ flood time $=$ the variation between flooding treatments, separately for infested and noninfested treatments; infest $x$ pathogen $\times$ flood time and infest $\times$ pathogen $\times$ rootstock $=$ the variation between pathogens and flooding treaments or rootstocks, respectively, within the infested treatments; infest $\times$ rootstock $\times$ flood time $=$ the interaction between rootstocks and flooding treatments, separately for infested and noninfested treatments.

${ }^{y}$ Analysis conducted using arcsin-transformed values.

'Shoot and root weights of individual inoculated plants were expressed as a percentage of the mean value of the five uninoculated controls for the same rootstock $\times$ flooding duration combination; those of uninoculated plants were expressed as a percentage of the mean value of the five unflooded controls for each rootstock

Phytophthora crown and root rots or suitabilities for wet soil conditions. Such interactions also may account for some of the inconsistencies in previous ratings noted above. For instance, Childers (1983) rated MM.111 and M.26 as "moderately resistant" and "susceptible" to root rot, respectively. However, in the present study, MM. 111 was generally the more susceptible of the two to crown and root rots caused by $P$. cactorum, $P$. cryptogea, and $P$. megasperma, whereas it was the markedly more tolerant of "wet feet" conditions in the absence of a pathogen. Similarly, although Rom and Brown (1979) found that growth suppression and mortality of 'Red Delicious' scions after 10 to 15 days of flooding treatments was far greater on MM.111 than on M.26 and attributed these differences to relative susceptibilities of the rootstock to anoxia, it is very possible that the rootstock were contaminated with $P$. cactorum when the experiment was initiated (Jeffers and Aldwinckle, 1988). If this were true, their data would support rather than contradict the results obtained in the present study. Furthermore, whereas $P$. cryptogea caused a $100 \%$ incidence of crown rot on 0.3 plants subjected to $72 \mathrm{~h}$ of flooding, 0.3 was the only rootstock on which $P$. megasperma caused no crown rot. Such examples collectively emphasize the importance of precisely identifying the cause of tree decline in wet soils when attempting to assess rootstock susceptibilities to such general symptoms as poor vigor or decay of root and crown tissues.

In controlled tests, the relative susceptibilities of apple rootstock to diseases caused by Phytophthora spp. generally have been evaluated on the basis of reactions following inoculation of fungal mycelium into wounded stems or excised twigs, sometimes with misleading results. Using such techniques, which they acknowledged "do not necessarily reflect (a rootstock's) liability to infection in the field," Sewell and Wilson (1959) determined MM. 106 and MM.104 to have "exceptionally high" and "high" levels of resistance, respectively, to $P$. cactorum, conclusions that were subsequently contradicted by orchard experience. In contrast, Barritt et al. (1990) used a related technique to compare rootstock reactions to $P$. cactorum and confirmed that MM. 106 is relatively susceptible, that M.9 is relatively resistant (Cummins and Aldwinckle, 1982; Jeffers and Wilcox, 1990), and supported the present indications that M.26 is relatively resistant. However, their data also suggested a comparable degree of susceptibility for MM.106 and domestic seedling, a rootstock that is generally regarded as among the most resistant in common usage (Jeffers and Wilcox, 1990; McIntosh, 1975). Whereas the limitations of the techniques employed in the present experiment are acknowledged, they may provide a more accurate measure of relative disease susceptibility than do stem or twig inoculation tests by more closely mimicking natural conditions under which Phytophthora crown and root rots develop.

Although extensive death of root and crown tissues and attendant fruit tree losses in waterlogged soils have sometimes been attributed strictly to the physiological effects of anoxia (Rem and Brown, 1979; Rowe and Beardsell, 1973), the present study clearly demonstrates that pathogenesis by Phytophthora spp. can produce such symptoms after periods of waterlogging insufficient to do so when these pathogens are not present. Flooding periods of the durations tested optimize the production and dispersal of infective 
zoospores of the Phytophthora spp. examined and may also increase host susceptibility to infection or colonization by these pathogens (Browne and Mircetich, 1988; Duniway, 1976; Wilcox and Mircetich, 1985a, 1985 b). However, the number and duration of flooding episodes necessary for the development of disease under field conditions is unknown. Browne and Mircetich (1988) recently reported that $P$. cactorum and $P$. cambivora caused significantly more damage on small 'Delicious' apple seedlings subjected to biweekly 4-h flooding periods than these same pathogens caused on the four rootstock subjected to weekly 24-h flooding periods in the present experiment; reasons for these different results are not known. Conversely, apple trees commonly survive waterlogged periods of several days or more under orchard conditions, even in soils known to be contaminated with Phytophthora spp. (personal observation). It is likely that in addition to genetic and edaphic factors, the ultimate development of Phytophthora root and crown rots on apple trees is influenced by qualitative and quantitative aspects of inoculum availability, seasonal fluctuations in disease susceptibility (Jeffers and Aldwinckle, 1986), and an undetermined number of additional physiological factors that influence an individual rootstock's susceptibility to initial attack and subsequent colonization by these pathogens.

\section{Literature Cited}

Barritt, B. H., R.P. Covey, and M.A. Dilley. 1990. In vitro testing of apple rootstock to Phytophthora cactorum. Fruit Var. J. 44:23-25.

Browne, G.T. and S.M. Mircetich. 1988. Effects of flood duration on the development of Phytophthora root and crown rot of apple. Phytopathology 78:846-851.

Childers, N.F. 1983. Modern fruit science (9th ed.). Hort. Publ., Gainesville, Fla. 583 p.

Cummins, J.N. and H.S. Aldwinckle. 1982. New and forthcoming apple rootstock. Fruit Var. J. 36:66-79.

Duniway, J.M. 1976. Movement of zoospores of Phytophthora cryptogea in soils of various textures and matric potentials, Phytopathology 66:877-882.

Jeffers, S.N. and H.S. Aldwinckle. 1986. Seasonal variation in extent and colonization of two apple rootstock by five species of Phytophthora. Plant Dis. 70:941-945.

Jeffers, S.N. and H.S. Aldwinckle. 1988. Phytophthora crown rot of apple trees: Sources of Phytophthora cactorum and P. cambivora as primary inoculum. Phytopathology 78:328-335.

Jeffers, S.N. and W.F. Wilcox. 1990. Phytophthora crown, collar, and root rots, p. 43-45, In: A.L. Jones and H.S. Aldwinckle (eds.). Compendium of apple and pear diseases. Amer. Phytopathol. Soc. Press, St. Paul, Minn.

McIntosh, D.L. 1975. Proceedings of the 1974 APDW workshop on crown rot of apple trees. Can. Plant Dis. Surv. 55:109-116.

Merwin, I. A., W.F. Wilcox, and W.C. Stiles. 1992. Influence of orchard ground cover management on the development of Phytophthora crown and root rots of apple, Plant Dis. 76:199-205.

Rem, R.C. and S.A. Brown. 1979. Water tolerance of clonal rootstock and peaches on seedling rootstock. Compact Fruit Tree 12:30-33.

Rowe, R.N. and D.V. Beardsell. 1973. Waterlogging of fruit trees. Hort. Abstr. 43:534-548.

Sewell, G.W.F. and J.F. Wilson. 1959. Resistance trials of some apple rootstock varieties to Phytophthora cactorum (L. \& C.) Schroet. J. Hort. Sci. 34:51-58.

Wilcox, W.F. 1989. Identity, virulence, and isolation frequency of seven Phytophthora spp. causing root rot of raspberry in New York. Phytopathology 79:93-101.

Wilcox, W.F. and S.M. Mircetich. 1985a. Influence of soil water matric potential on the development of Phytophthora root and crown rots of cherry. Phytopathology 75:648-653.

Wilcox, W.F. and S.M. Mircetich. 1985b. Effects of flooding duration on the development of Phytophthora root and crown rots of cherry. Phytopathology 75:1451-1455. 